\title{
E-LEARNING DALAM PEMBELAJARAN
}

\author{
Oleh: Ade Kusmana*
}

\begin{abstract}
This article deals the e-learning and how it develops. E-learning system is badly needed to keep up with the development supported by information technology leading to digital era both process and content. To develop an e-learning system, it should be preceded by a user-need analysis. In line with the paradigm of planned system and software, the user-need analysis is of great importance as it is a basis of design. These are designed to avoid a bad implementation process of e-learning system, which mainly due to the irrelevance of developed system to the real need of users.
\end{abstract}

KEYWORDS: E-learning, technology information, learning.

SEIRING dengan perkembangan Teknologi Informasi (TI) yang semakin pesat, kebutuhan akan suatu konsep dan mekanisme belajar mengajar (pendidikan) berbasis TI menjadi tidak terelakkan lagi. Konsep yang kemudian terkenal dengan sebutan e-learning ini membawa pengaruh terjadinya proses transformasi pendidikan konvensional ke dalam bentuk digital, baik secara isi (contents) dan sistemnya.

Depdiknas juga intensif mendorong pengembangan e-learning untuk memberikan layanan dan kesempatan pada masyarakat luas yang selama ini tidak terjangkau dengan sistem konvensional secara tatap muka. Sehingga dengan adanya model e-learning ini memungkinkan untuk mencapai sasaran yang lebih luas di seluruh Indonesia (to reach the unreached).

Dalam perspektif yang lebih luas, dunia saat ini sedang memasuki era yang ditandai dengan gencarnya inovasi teknologi dan peluang ekonomi yang belum pernah terbayangkan sebelumnya. Perubahan-perubahan besar terjadi dalam bidang teknologi, politik, sosial dan ekonomi. Segala perubahan ini telah menyebabkan terjadinya pergeseran dalam berbagai bidang yang antara lain adalah; masyarakat industri ke masyarakat informasi, teknologi yang dipaksakan ke teknologi tinggi (hightech), ekonomi nasional ke perekonomian dunia, kebutuhan jangka pendek ke jangka panjang, sistem sentralisasi ke sistem desentralisasi, bantuan kelembagaan

*Kandidat Doktor Linguistik pada Program Pascasarjana UNJ ini adalah Dosen Bahasa Indonesia pada Universitas Jambi 
berpindah ke swakarsa, dari pola hirarchy ke jaringan kerja (networking), dari pilihan terbatas ke banyak pilihan.

Pengembangan e-learning ini juga memang menjadi kecenderungan dan pilihan karena adanya perubahan dalam kehidupan. Pada era globalisasi saat ini terjadi perubahan paradigma dalam dunia pendidikan. Pendidikan yang berlangsung sekarang setidaknya menghadapi dua tantangan. Tantangan yang pertama berasal dari adanya perubahan pandangan terhadap belajar itu sendiri. Pandangan behaviorisme yang mengutamakan stimulus dan respons tidak cukup untuk dapat memberikan hasil optimal. Pembaharuan paradigma belajar melalui pandangan konstruktivisme dan pergeseran-pergeseran yang terjadi karena adanya kemajuan teknologi informasi dan komunikasi merupakan dua hal yang sangat sejalan dan saling memperkuat.

Tantangan kedua yang dihadapi oleh dunia pendidikan saat ini adalah kemajuan teknologi informasi dan komunikasi yang begitu pesat, yang menawarkan berbagai kemudahan dalam pembelajaran. Kemajuan teknologi ini memungkinkan terjadinya pergeseran orientasi belajar dari outside-guided menjadi self-guided. Selain itu teknologi juga memainkan peranan penting dalam memperbaharui konsepsi pembelajaran yang semula semata-mata fokus pada pembelajaran sebagai suatu penyajian berbagai pengetahuan menjadi pembelajaran sebagai suatu bimbingan agar mampu melakukan eksplorasi sosial budaya yang kaya akan pengetahuan.

Perangkat berbasis teknologi lainnya yang diharapkan dapat digunakan dalam upaya mengembangkan lingkungan belajar yang lebih produktif adalah video discs, multimedia/hypermedia, e-mail dan internet, di samping piranti lunak Computer Assisted Instruction/Intelligent Computer Assisted Instruction (CAI/ICAI).

Oleh karena itu kebutuhan akan multimedia interaktif semakin dirasakan, mengingat kondisi perkembangan Teknologi Informasi (TI) semakin berkembang pesat. Dalam dunia pendidikan misalnya siswa mulai dari pra-sekolah, SD, SMP dan SMU/SMK dituntut untuk mengenal TI sejak dini. Kebutuhan ini tidak hanya sebagai wacana tetapi dilegalisasi melalui terbitnya Kurikulum yang memasukan mata pelajaran Teknologi Informasi dan Komunikasi (TIK) di sekolah, lebih khusus lagi SMK TI secara spesifik mempelajari TI sebagai suatu keahlian produktif. Untuk menunjang masuknya TI di sekolah, pemerintah secara bertahap membantu sekolah-sekolah dengan memberikan perangkat hardware komputer sebagai alat praktek dan ditunjang dengan diberikannya BOM (bantuan perasional manajemen) yang salah satunya harus dibelanjakan untuk membeli software komputer untuk menunjang pembelajaran TI dan peng- 
uasaan materi pelajaran umum dengan bantuan TI. Dengan demikian jelas bahwa kebutuhan bahan pembelajaran berbasis ICT sebagai alat untuk membantu siswa menguasai TI dan materi pelajaran umum lainnya dengan lebih cepat, menyenangkan dan meningkatkan hasil belajar, menjadi kebutuhan yang mendesak untuk tercapainya kualitas pembelajaran yang diharapkan.

Paper ini bertujuan menjawab pertanyaan tentang hal-hal yang bersifat mendasar kaitannya dengan e-learning secara umum yang menggunakan platform Teknologi Informasi dan Komunikasi (TIK). Teknologi yang disebut oleh McLuhan sebagai perpanjangan tangan manusia (the extension of human being) dalam menyelesaikan persoalannya sehingga dalam hal ini TIK sering disebut memiliki fungsi enabling atau memungkinkan hal yang sebelumnya tidak mungkin baik dalam hal komputasi maupun dalam hal cara berkomunikasi dan berkolaborasi. Makalah ini akan memokuskan pembahasan e-learning dalam pembelajaran. Bagaimana seharusnya aplikasi e-learning dikembangkan dengan menyeimbangkan antara kebutuhan pengguna dan keinginan dari pengembang. Penjelasan akan dimulai dari pengertian e-learning, TIK dalam pembelajaran, prosedur dasar e-learning, dan proses belajar dalam e-learning.

\section{APA, MENGAPA E-LEARNING}

Apa itu e-learning? E-learning merupakan suatu teknologi informasi yang relatif baru di Indonesia. E-learning terdiri dari dua bagian, yaitu ' $\mathrm{e}$ ' yang merupakan singkatan dari 'electronic' dan 'learning' yang berarti 'pembelajaran'. Jadi e-learning berarti pembelajaran dengan menggunakan jasa bantuan perangkat elektronika, khususnya perangkat komputer. Karena itu, maka e-learning sering disebut pula dengan 'online course'. Dalam berbagai literatur, e-learning didefinisikan sebagai berikut:

E-learning is a generic term for all technologically supported learning using an array of teaching and learning tools as phone bridging, audio and videotapes, teleconferencing, satellite transmissions, and the more recognized web-based training or computer aided instruction also commonly referred to as. ${ }^{1}$

Dengan demikian maka e-learning atau pembelajaran melalui online adalah pembelajaran yang pelaksaannya didukung oleh jasa teknologi seperti telepon, audio, videotape, transmisi satelit atau komputer.

Dalam perkembanganya, komputer dipakai sebagai alat bantu pembelajaran, karena itu dikenal dengan istilah (CBL) atau computer assisted learning (CAL). Saat pertama kali komputer mulai diperkenalkan khususnya untuk pembelajaran, maka komputer menjadi popular di kalangan 
anak didik. Hal ini dapat dimengerti karena berbagai variasi teknik mengajar bisa dibuat dengan bantuan komputer tersebut. Maka setelah itu teknologi pembelajaran terus berkembang dan dikelompokkan menjadi dua yaitu :

- Technology-based learning

- Technology-based Web-learning

- Technology based-learning ini pada prinsipnya terdiri dari dua, yaitu audio (audio tape, radio, voice mail, telepon) an video information technologies (video tape, video text, video messaging). Sedangkan technology based weblearning pada dasarnya adalah data information technologies (bulletin board, internet, email, tele-collaboration).

Dalam pelaksanaan pembelajaran sehari-hari, yang sering dijumpai adalah kombinasi dari teknologi yang dituliskan di atas (audio/data, video/data, audio/video). Teknologi ini juga sering dipakai pada pendidikan jarak jauh, dimaksudkan agar komunikasi antara murid dan guru bisa terjadi dengan keunggulan teknologi e-learning ini. Sedangkan interaksi antara guru dan murid bisa dilaksanakan melalui cara langsung (synchronous) atau tidak langsung, misalnya pesan direkam dahulu sebelum digunakan. Cara ini dikenal dengan nama e-synchronous.

Karakteristik e-learning antara lain adalah:

- Memanfaatkan jasa teknologi elektronik; dimana guru dan siswa, siswa dan sesama siswa atau guru dan sesama guru dapat berkomunikasi dengan relatif mudah dengan tanpa dibatasi oleh hal-hal yang protokelor;

- Menggunakan bahan ajar bersifat mandiri (self learning materials) disimpan di komputer sehinga dapat diakses oleh guru dan siswa kapan saja dan dimana saja dan yang bersangkutan memerlukanya; dan

- Memanfaatkan jadwal pembelajaran, kurikulum, hasil kemajuan belajar dan hal-hal yang berkaitan dengan administrasi pendidikan dapat dilihat setiap saat di komputer.

Menurut Miarso, Pemanfaatan e-learning tidak terlepas dari jasa internet. Karena teknik pembelajaran yang tersedia di internet begitu lengkap, maka hal ini akan mempengaruhi tugas guru dalam proses pembelajaran. Dahulu, proses belajar-mengajar didominasi oleh peranan guru, karena itu disebut the era of teacher. Kini, proses belajar-mengajar, banyak didominasi oleh peran guru dan buku (the era of teacher and book) dan pada masa mendatang proses belajar mengajar akan didominasi oleh guru, buku, dan teknologi (the era of teacher, book, and technology). ${ }^{2}$

\section{Apa Kelebihan dan Kekurangan E-learning?}

Menyadari bahwa melalui internet dapat ditemukan berbagai informasi yang dapat diakses secara mudah, kapan saja dan dimana saja, maka 
pemanfaatan internet menjadi suatu kebutuhan. Bukan itu saja, pengguna internet bisa berkomunikasi dengan pihak lain dengan cara yang sangat mudah melalui teknik e-moderating yang tersedia di internet.

Dari berbagai pengalaman dan juga dari berbagai informasi yang tersedia di literatur, memberikan petunjuk tentang manfaat penggunaan internet, khususnya dalam pendidikan terbuka dan jarak jauh, antara lain dapat disebutkan sebagai berikut.

- Tersedianya fasilitas e-moderating di mana guru dan murid dapat berkomunikasi dengan mudah melalui fasilitas internet secara regular atau kapan saja kegiatan berkomunikasi itu dilakukan dengan tanpa dibatasi oleh jarak, tempat, dan waktu.

- Guru dan siswa dapat menggunakan bahan ajar atau petunjuk belajar yang tersruktur dan terjadwal melalui internet, sehingga keduanya bisa saling menilai sampai berapa jauh bahan ajar dipelajari.

- Siswa dapat belajar atau me-review bahan ajar setiap saat dan di mana saja kalau diperlukan mengingat bahan ajar tersimpan di komputer.

- Bila siswa memerlukan tambahan informasi yang berkaitan dengan bahan yang dipelajarinya, ia dapat melakukan akses di internet.

- Baik guru maupun siswa dapat melaksanakan diskusi melalui internet yang dapat diikuti dengan jumlah peserta yang banyak, sehingga menambah ilmu pengetahuan dan wawasan yang lebih luas.

- Berubahnya peran siswa dari yang biasanya pasif menjadi aktif .

- Relatif lebih efisien. Misalnya bagi yang mereka tinggal jauh dari perguruan tinggi atau sekolah konvensional, bagi mereka yang sibuk bekerja, bagi mereka yang bertugas di kapal, di luar negeri, dan sebagainya.

Walaupun demikian pemanfaatan internet untuk pembelajaran atau e-learning juga tidak terlepas dari berbagai kekurangan. Berbagai kritik antara lain dapat disebutkan sebagai berikut:

1. Kurangnya interaksi antara guru dan siswa bahkan antar-siswa itu sendiri. Kurangnya interaksi ini bisa memperlambat terbentuknya values dalam proses belajar-mengajar.

2. Kecenderungan mengabaikan aspek akademik atau aspek sosial dan sebaliknya mendorong tumbuhnya aspek bisnis.

3. Proses belajar dan mengajarnya cenderung ke arah pelatihan daripada pendidikan.

4. Berubahnya peran guru dan yang semula menguasai teknik pembelajaran konvensional, kini juga dituntut mengetahui teknik pembelajaran yang menggunakan ICT.

5. Siswa yang tidak mempunyai motivasi belajar yang tinggi cenderung gagal. 
6. Tidak semua tempat tersedia fasilitas internet (mungkin hal ini berkaitan dengan masalah tersedianya listrik, telepon, ataupun komputer).

7. Kurangnya penguasaan komputer.

\section{Faktor Apa Yang Dipertimbangkan dalam Memanfaatkan E-learning?}

Ahli-ahli pendidikan dan internet menyarankan beberapa hal yang perlu diperhatikan sebelum seseorang memilih internet untuk kegiatan pembelajaran, ${ }^{3}$ antara lain:

\section{Analisis Kebutuhan (Need Analysis)}

Dalam tahapan awal, satu hal yang perlu dipertimbangkan adalah apakah memang memerlukan e-learning. Untuk menjawab pertanyaan ini tidak dapat dijawab dengan perkiraan atau dijawab berdasarkan atas sasaran orang lain. Sebab setiap lembaga menentukan teknologi pembelajaran sendiri yang berbeda satu sama lain. Untuk itu perlu diadakan analisis kebutuhan. Kalau analisis ini dilaksanakan dan jawabannya adalah membutuhkan e-learning maka tahap berikutnya adalah membuat studi kelayakan, yang komponen penilaiannya adalah:

1. Apakah secara teknis dapat dilaksanakan misalnya apakah jaringan internet bisa dipasang, apakah infrasruktur pendukungnya, seperti telepon, listrik, komputer tersedia, apakah ada tenaga teknis yang bisa mengoperasikanya tersedia.

2. Apakah secara ekonomis menguntungkan, misalnya apakah dengan $e$ learning kegiatan yang dilakukan menguntungkan atau apakah return on investment-nya lebih besar dari satu.

3. Apakah secara sosial penggunaan e-learning tersebut diterima oleh masyarakat.

\section{Rancangan Instruksional}

Dalam menentukan rancangan instruksional ini perlu dipertimbangkan aspek-aspek:4

a. Course content and learning unit analysis, seperti isi pelajaran, cakupan, topik yang relevan dan satuan kredit semester.

b. Learner analysis, seperti latar belakang pendidikan siswa, usia, jenis kelamin, status pekerjaan, dan sebagainya.

c. Learning context analysis, seperti kompetisi pembelajaran apa yang diinginkan hendaknya dibahas secara mendalam di bagian ini.

d. Instructional analysis, seperti bahan ajar apa yang dikelompokan menurut kepentingannya, menyusun tugas-tugas dari yang mudah hingga yang sulit, dan seterusnya.

e. State instructional objectives, Tujuan instuksional ini dapat disusun berdasarkan hasil dari analisis instruksional. 
f. Construct criterion test items, penyusunan tes ini dapat didasarkan dari tujuan instruksional yang telah ditetapkan.

g. Select instructional strategy, strategi instruksional dapat ditetapkan berdasarkan fasilitas yang ada.

\section{Tahap Pengembangan}

Berbagai upaya dalam pengembangan e-learning bisa dilakukan mengikuti perkembangan fasilitas ICT yang tersedia hal ini kadang-kadang fasilitas ICT tidak dilengkapi dalam waktu yang bersamaan. Begitu pula halnya dengan prototype bahan ajar dan rancangan intruksional yang akan dipergunakan terus dipertimbangkan dan dievaluasi secara berkesinambungan.

\section{Pelaksanaan}

Prototype yang lengkap bisa dipindahkan ke komputer (LAN) dengan menggunakan format misalnya format HTML. Uji terhadap prototype hendaknya terus menerus dilakukan. Dalam tahapan ini sering kali ditemukan berbagai hambatan, misalnya bagaimana menggunakan management course tool secara baik, apakah bahan ajarnya benar-benar memenuhi standar bahan ajar mandiri.

\section{Evaluasi}

Sebelum program dimulai, ada baiknya dicobakan dengan mengambil beberapa sampel orang yang dimintai tolong untuk ikut mengevaluasi. Proses dari kelima tahapan diatas diperlukan waktu yang relatif lama, karena prototype perlu dievaluasi secara terus menerus. Masukan dari orang lain atau dari siswa perlu diperhatikan secara serius. Proses dari tahapan satu sampai lima dapat dilakukan berulang kali, karena prosesnya terjadi terus-menerus.

Akhirnya harus pula diperhatikan masalah-masalah yang sering dihadapi sebagai berikut:

a. Masalah akses untuk bisa melaksanakan e-learning seperti ketersediaan jaringan internet, listrik, telepon, dan infrastruktur yang lain.

b. Masalah ketersediaan software (peranti lunak). Bagaimana mengusahakan peranti lunak yang tidak mahal.

c. Masalah dampaknya terhadap kurikulum yang ada.

d. Masalah skill dan knowledge.

e. Attitude terhadap ICT.

E-learning merupakan aplikasi internet yang dapat menghubungkan antara pendidik dan peserta didik dalam sebuah ruang belajar online. E- 
learning tercipta untuk mengatasi keterbatasan antara pendidik dan peserta didik, terutama dalam hal waktu dan ruang. Dengan e-learning maka pendidik dan peserta didik tidak harus berada dalam satu dimensi ruang dan waktu. Proses pendidikan dapat berjalan kapan saja dengan mengabaikan kedua hal tersebut.

Pemanfaatan e-learning sangat bergantung pada bagaimana pengguna memandang atau menilai e-learning tersebut. Namun umumnya penggunaan teknologi tersebut tergantung dari:

1. Apakah teknologi itu memang sudah merupakan kebutuhan;

2. Apakah fasilitas pendukungnya sudah memadai;

3. Apakah didukung oleh dana yang memadai; dan

4. Apakah ada dukungan dari pembuat kebijakan.

\section{TEKNOLOGI INFORMASI DAN KOMUNIKASI DALAM PEMBE- LAJARAN}

Indonesia sebagai negara berpopulasi tertinggi ke-4 tentunya memiliki banyak tantangan di bidang pendidikan. Beberapa tantangan diantaranya adalah: masih banyaknya anak usia sekolah yang belum dapat menikmati pendidikan dasar 9 tahun: angka partisipasi anak berusia sekolah 7-12 tahun untuk bersekolah masih dibawah 80\% (APK SMP 85,22 dan APK SMA 52,2). Tantangan berikutnya adalah (1) tidak meratanya penyebaran sarana dan prasarana pendidikan/sekolah (sebagai contoh: tidak semua sekolah memiliki saluran telepon, apalagi koneksi internet): Kota vs Desa/Daerah Terpencil/Daerah Perbatasan, Indonesia Barat vs Indonesia Timur. (2) Tidak seragamnya dan masih rendahnya mutu pendidikan di setiap jenjang sekolah yang ditandai dengan tingkat kelulusan UN yang rendah, demikian pula nilai UN yang diperoleh siswa. (3) Rendahnya kualitas kompetensi tenaga pengajar, dimana dari jumlah guru yang ada 2.692.217, ternyata yang memenuhi persyaratan (tersertifikasi) hanya 727.381 orang atau baru $27 \%$ dari total jumlah guru di Indonesia. Tantangan yang tidak kalah penting adalah (4) rendahnya tingkat pemanfaatan TIK di sekolah yang telah memiliki fasilitas TIK (utilitas rendah), di sisi lain tidak semua sekolah mempunyai sarana TIK yang memadai.

Pada dasarnya TIK bukan hanya komputer dan internetnya, TIK juga melingkupi media informasi seperti radio dan televisi serta media komunikasi seperti telepon maupun telepon seluler dengan SMS, MMS, Music Player, Video Player, Kamera Foto Digital, dan Kamera Video Digital-nya serta e-Book Reader-nya. Jadi banyak media alternatif yang dapat dipilih oleh pengajar untuk menciptakan suasana pembelajaran yang menyenangkan dan berkesan. TIK yang termanfaatkan dengan baik dan tepat di dalam pendidikan akan: memperluas kesempatan belajar, meningkatkan efisiensi, 
meningkatkan kualitas belajar, meningkatkan kualitas mengajar, memfasilitasi pembentukan keterampilan, mendorong belajar sepanjang hayat berkelanjutan, meningkatkan perencanaan kebijakan dan manajemen, serta mengurangi kesenjangan digital.

Bagaimana peran guru dan siswa? Di dalam proses belajar-mengajar tentunya ada subjek dan objek yang berperan secara aktif, dinamik dan interaktif di dalam ruang belajar, baik di dalam kelas maupun di luar kelas. Guru dan siswa sama-sama dituntut untuk membuat suasana belajar dan proses transfer of knowledge-nya berjalan menyenangkan serta tidak membosankan. Oleh karena itu penataan peran guru dan siswa di dalam kelas yang mengintegrasikan TIK di dalam pembelajaran perlu dipahami dan dimainkan dengan sebaik-baiknya.

Kini di era pendidikan berbasis TIK, peran guru tidak hanya sebagai pengajar semata namun sekaligus menjadi fasilitator, kolaborator, mentor, pelatih, pengarah dan teman belajar bagi siswa. Karenanya guru dapat memberikan pilihan dan tanggung jawab yang besar kepada siswa untuk mengalami peristiwa belajar. Dengan peran guru sebagaimana dimaksud, maka peran siswa pun mengalami perubahan, dari partisipan pasif menjadi partisipan aktif yang banyak menghasilkan dan berbagi (sharing) pengetahuan/keterampilan serta berpartisipasi sebanyak mungkin sebagaimana layaknya seorang ahli. Di sisi lain siswa juga dapat belajar secara individu, sebagaimana halnya juga kolaboratif dengan siswa lain.

Untuk mendukung proses integrasi TIK di dalam pembelajaran, maka manajemen sekolah, guru dan siswa harus memahami 9 (sembilan) prinsip integrasi TIK dalam pembelajaran yang terdiri atas prinsip-prinsip:

1. Aktif: memungkinkan siswa dapat terlibat aktif oleh adanya proses belajar yang menarik dan bermakna.

2. Konstruktif: memungkinkan siswa dapat menggabungkan ide-ide baru kedalam pengetahuan yang telah dimiliki sebelumnya untuk memahami makna atau keinginantahuan dan keraguan yang selama ini ada dalam benaknya.

3. Kolaboratif: memungkinkan siswa dalam suatu kelompok atau komunitas yang saling bekerjasama, berbagi ide, saran atau pengalaman, menasehati dan memberi masukan untuk sesama anggota kelompoknya.

4. Antusiastik: memungkinkan siswa dapat secara aktif dan antusias berusaha untuk mencapai tujuan yang diinginkan.

5. Dialogis: memungkinkan proses belajar secara inherent merupakan suatu proses sosial dan dialogis dimana siswa memperoleh keuntungan dari proses komunikasi tersebut baik di dalam maupun luar sekolah. 
6. Kontekstual: memungkinkan situasi belajar diarahkan pada proses belajar yang bermakna (real-world) melalui pendekatan "problem-based atau case-based learning"

7. Reflektif: memungkinkan siswa dapat menyadari apa yang telah ia pelajari serta merenungkan apa yang telah dipelajarinya sebagai bagian dari proses belajar itu sendiri.

8. Multisensory: memungkinkan pembelajaran dapat disampaikan untuk berbagai modalitas belajar (multisensory), baik audio, visual, maupun kinestetik.

9. High order thinking skills training: memungkinkan untuk melatih kemampuan berpikir tingkat tinggi (seperti problem solving, pengambilan keputusan, dan lain-lain) serta secara tidak langsung juga meningkatkan "ICT dan media literacy".

Sebagaimana telah dijelaskan di atas, maka bukti otentik terjadinya pembelajaran berbasis TIK dapat kita cermati dari Rencana Pelaksanaan Pembelajaran (RPP) yang disusun dan implementasinya yang dilaksanakan oleh setiap guru mata pelajaran di sekolah. RPP yang mengintegrasikan TIK di dalam pembelajaran dapat disusun melalui 2 (dua) pendekatan, yaitu pendekatan idealis dan pendekatan pragmatis. Pertama, Pendekatan Idealis dapat dimulai dengan menentukan topik, kemudian menentukan tujuan pembelajaran yang ingin dicapai; dan menentukan aktivitas pembelajaran dengan memanfaatkan TIK (seperti modul, LKS, program audio, VCD/DVD, CD-ROM, bahan belajar online di internet, atau alat komunikasi sinkronous dan asinkronous lainnya) yang relevan untuk mencapai tujuan pembelajaran tersebut. Kedua, Pendekatan Pragmatis dapat diawali dengan mengidentifikasi TIK (seperti buku, modul, LKS, program audio, VCD/DVD, CD-ROOM, bahan belajar online di internet, atau alat komunikasi sinkronous dan asinkronous lainnya) yang ada atau mungkin bisa dilakukan atau digunakan, kemudian memilih topik-topik apa yang bisa didukung oleh keberadaan TIK tersebut, dan diakhiri dengan merencanakan strategi pembelajaran yang relevan untuk mencapai kompetensi dasar dan indikator capaian hasil belajar dari topik pelajaran tersebut.

Adapun strategi yang dapat dipilih sesuai dengan kedua pendekatan tersebut adalah strategi: Resources-based learning (pembelajaran berbasis sumber daya), Case/problem-based learning (pembelajaran berbasis permasalahan/ kasus sehari-hari), Simulation-based learning (pembelajaran berbasis simulasi), dan Colaborative-based learning (pembelajaran berbasis kolaborasi).

Bagaimana peran TVE dan Jardiknas? Sebagaimana diketahui bersama, tantangan terbesar negara kita dalam mencerdaskan bangsa 
adalah akses setiap masyarakat Indonesia ke sumber-sumber pengetahuan dan informasi pendidikan. Oleh karena itulah Depdiknas berupaya menjawab tantangan tersebut dengan inisiatif yang penuh inovasi melalui penyelenggaraan siaran TV Edukasi yang diresmikan pada tahun 2004 ini merupakan televisi yang mengkhususkan pada siaran pendidikan, termasuk program pembelajaran. Kemudian pada tahun 2006, Depdiknas menggelar Jardiknas (Jejaring Pendidikan Nasional) yang merupakan jaringan TIK nasional terbesar yang dimanfaatkan oleh Depdiknas untuk keperluan komunikasi data administrasi, konten pembelajaran, serta informasi dan kebijakan pendidikan.

TVE yang kini telah memiliki saluran 2 untuk Guru ini memiliki pola siaran: Informasi yang berisikan materi: News, Pola siaran yang berisikan Kebijakan, Profil Guru, dan sebagainya; Tutorial (Pendidikan Formal) yang berisikan materi: pembelajaran berdasarkan kurikulum Program SD, SMP, SMA, SMK, PJJ S-1 PGSD konsorsium dan Program S1 PGSD Non Konsorsium; dan Pengayaan yang berisikan materi: pengayaan dan materi yang bertujuan untuk meningkatkan kompetensi Guru.

Sedangkan Jardiknas saat ini memiliki 1.072 node (simpul) Zona Kantor dan Perguruan Tinggi yang tersebar di 33 provinsi dan 456 kabupaten/kota. Jardiknas yang berpusat di NOC Pustekkom Ciputat Banten dan NOC Telkom Karet Jakarta ini difasilitasi bandwidth intranet, internet domestik dan internet internasional yang cukup memadai untuk mendukung e-administrasi dan e-pembelajaran di Indonesia. Dalam waktu dekat - dalam rangka memenuhi Inpres nomor 5 tahun 2008 - Depdiknas akan mengembangkan Jardiknas Zona Sekolah untuk 15.000 sekolah dan Jardiknas Zona Perorangan untuk 7.943 tenaga pengajar yang memiliki laptop. Media koneksi Jardiknas Zona Sekolah berorientasi static internet (fixed), sedangkan Jardiknas Zona Perorangan berorientasi kepada mobile internet.

Bagaimana isinya? Kita memahami bahwa infrastruktur semegah apapun tidak akan berarti sama sekali jika tidak ada konten bermanfaat di dalamnya. Setiap hari pengguna internet berselancar di dunia maya hanya untuk mencari konten yang benar-benar diinginkannya secara instan, baik didorong oleh rasa keingintahuan terhadap suatu fenomena maupun sekedar membuktikan sebuah informasi. Demikian halnya konten pendidikan yang disajikan melalui TVE maupun disediakan melalui Jardiknas. Beberapa konten e-learning yang selama ini cukup mendukung pembelajaran berbasis TIK adalah: Bimbingan Belajar Online, Bank Soal Online, Uji Kompetensi Online, Smart School, Telekolaborasi, Digital Library, Research Network, dan Video Conference PJJ. 
Salah satu konten yang cukup menyita perhatian publik akhir-akhir ini adalah program buku murah yang dikemas di dalam aplikasi Buku Sekolah Elektronik (BS) yang dapat diakses melalui: bse.depdiknas.go.id. BSE merupakan langkah reformasi di bidang perbukuan dimana Depdiknas telah membeli Hak Cipta buku-buku teks pelajaran SD, SMP, SMA, dan SMK tersebut. Softcopy buku-buku teks pelajaran tersebut didistribusikan melalui web BSE agar guru atau masyarakat dapat mengakses, mengunduh, mencetak, mendistribusikan, atau menjualnya sesuai HET (Harga Eceran Tertinggi) dimana saja dan kapan saja. Selain BSE versi online yang dapat diakses melalui internet, Depdiknas juga telah menyediakan dan mendistribusikan BSE versi offline yang dikemas di dalam cakram padat DVD.

Demikian strategi pengembangan pembelajaran berbasis TIK yang terus-menerus dikembangkan dan didukung oleh Depdiknas melalui sejumlah inisiatif dan inovasi di bidang teknologi pembelajaran, teknologi informasi dan teknologi komunikasi. Kita dapat berharap suatu saat nanti TVE dan Jardiknas dapat menjadi Pusat Konten Pembelajaran yang dapat diakses dimana saja dan kapan saja melalui koneksi Kabel, Nirkabel \& Satelit.

\section{PROSEDUR DASAR E-LEARNING}

TIK memiliki tiga falsafah dasar, yakni kecepatan, jejaring (network) dan efisiensi. Oleh karena itu jika kita ingin menguasai, mengembangkan dan menggunakan TIK, maka tiga dasar falsafah dasar tadi mutlak diterapkan. Era global adalah era dimana setiap pihak harus bergerak cepat dalam segala hal agar tidak ketinggalan. Dalam era global, pembangunan jejaring juga adalah keniscayaan yang harus disertai dengan efisiensi organisasi di semua lini.

Saat ini komputer bukan lagi merupakan barang mewah, alat ini sudah digunakan di berbagai bidang pekerjaan seperti halnya pada bidang pendidikan. Pada awalnya komputer dimanfaatkan di sekolah sebagai penunjang kelancaran pekerjaan bidang administrasi dengan memanfaatkan software Microsoft Word, Excel, PowerPoint dan Access. Dengan masuknya materi Teknologi Informasi dan Komunikasi dalam kurikulum baru, maka peranan komputer sebagai salah satu komponen utama dalam TIK mempunyai posisi yang sangat penting sebagai salah satu media pembelajaran. Visi mata pelajaran Teknologi Informasi dan Komunikasi dalam kurikulum adalah:

- Agar siswa dapat dan terbiasa menggunakan perangkat Teknologi Informasi dan Komunikasi secara tepat dan optimal untuk mendapat- 
kan dan memproses informasi dalam kegiatan belajar, bekerja, dan aktivitas lainnya sehingga siswa mampu berkreasi, mengembangkan sikap imaginatif, mengembangkan kemampuan eksplorasi mandiri, dan mudah beradaptasi dengan perkembangan baru di lingkungannya.

- Melalui mata pelajaran Teknologi Informasi dan Komunikasi diharapkan siswa dapat terlibat pada perubahan pesat dalam kehidupan yang mengalami penambahan dan perubahan dalam penggunaan beragam produk teknologi informasi dan komunikasi.

- Siswa menggunakan perangkat Teknologi Informasi dan Komunikasi untuk mencari, mengeksplorasi, menganalisis, dan saling tukar informasi secara efisien dan efektif.

- Dengan menggunakan Teknologi Informasi dan Komunikasi, siswa akan dengan cepat mendapatkan ide dan pengalaman dari berbagai kalangan. Penambahan kemampuan siswa karena penggunaan Teknologi Informasi dan Komunikasi akan mengembangkan sikap inisiatif dan kemampuan belajar mandiri, sehingga siswa dapat memutuskan dan mempertimbangkan sendiri kapan dan dimana penggunaan Teknologi Informasi dan Komunikasi secara tepat dan optimal, termasuk apa implikasinya saat ini dan dimasa yang akan datang.

Teknologi Informasi dan Komunikasi (TIK) mencakup dua aspek, yaitu Teknologi Informasi dan Teknologi Komunikasi. Teknologi Informasi, meliputi segala hal yang berkaitan dengan proses, penggunaan sebagai alat bantu, manipulasi, dan pengelolaan informasi. Teknologi Komunikasi merupakan segala hal yang berkaitan dengan penggunaan alat bantu untuk memproses dan mentransfer data dari perangkat yang satu ke lainnya. Karena itu, Teknologi Informasi dan Teknologi Komunikasi adalah suatu padanan yang tidak terpisahkan yang mengandung pengertian luas tentang segala kegiatan yang terkait dengan pemrosesan, manipulasi, pengelolaan, dan transfer/pemindahan informasi antar media.

Dengan melihat isi dari kurikulum tersebut, diharuskan mengintegrasikan TIK dalam proses belajar mengajar di sekolah bukan hanya untuk mata pelajaran teknologi dan informasi saja tetapi juga untuk semua mata pelajaran. Melihat kondisi TIK pada saat ini dan perkembangannya di masa datang, kita harus mempersiapkan diri dan melakukan perencanaan yang matang dalam mengimplementasikan TIK di sekolah. Mengamati Program Pengembagan TIK yang dilakukan Depdiknas Untuk mengejar ketertinggalan pemanfaatan TIK di sekolah dari negara lain.

Ada tiga posisi penting di Depdiknas dalam program pengembangan TIK, yaitu: 
1. Bidang kejuruan, TIK menjadi salah satu jurusan di SMK. Pengembangan TIK secara teknis baik hardware dan software masuk dalam kurikum pendidikan. Dibentuknya ICT center di seluruh Indonesia. Untuk menghubungkan sekolah-sekolah di sekitar ICT center dibangun WAN (Wireless Area Network) Kota.

2. Pustekkom, sebagai salah satu ujung tombak dalam pengembangan TV pendidikan interaktif, e-learning dan ESMA. Program ini bertujuan untuk mempersempit jurang perbedaan kualitas pendidikan antara kota besar dengan daerah.

3. Jardiknas (Jejaring Pendidikan Nasional), bertujuan untuk mengintegrasikan kedua program di atas agar terbentuk sebuah jaringan yang menghubungkan semua sekolah di Indonesia. Sehingga diperkirakan di masa depan semua sekolah di Indonesia akan terkoneksi dengan internet. Melihat program yang diadakan oleh Depdiknas kita bisa memanfaatkan fasilitas tersebut karena bersifat terbuka.

\section{PROSES BELAJAR DALAM E-LEARNING}

Secara filosofis, pelaksanaan e-learning mengandung dua konsekuensi. Konsekuensi pertama, menuntut diterapkannya sistem belajar mandiri (independent learning). Artinya setiap peserta didik memiliki otonomi untuk menentukan tiga opsi berikut: (1) apa yang akan mereka pelajari; (2) kapan, dimana, bagaimana mereka mempelajarinya; dan (3) kapan, bagaimana mereka membuktikan keberhasilan belajarnya.

Konsekuensi kedua, dioptimalkannya media komunikasi, khususnya teknologi telekomunikasi secara tepat guna dan sesuai kebutuhan. Media komunikasi atau teknologi telekomunikasi tersebut diantaranya adalah media cetak (buku atau modul cetak, surat, dll), media audio (cassette audio dan atau radio), media audio visual (video (CD/DVD) dan atau televisi), media komputer (CAI (multimedia interaktif), e-book, pdf, wmv, dan lainlain), media internet (web, email, milist, chat, dan lain-lain), media telekonferensi (audioconference, videoconference, computer/ webconference), media mobile (handphone). Oleh karena itu, dalam konteks saat ini, penyelenggaraan belajar Jarak Jauh dapat dikatakan sudah memasuki generasi kelima. Generasi pertama, memanfaatkan korespondensi (surat-menyurat). Naik ke generasi kedua seiring dengan adanya potensi media cetak yang dinamakan modul cetak (bahan belajar yang dirancang khusus untuk belajar mandiri). Generasi ketiga sudah mengkombinasikan pemanfaatan radio, karena saat itu telah ada radio. Generasi keempat, ditambah lagi dengan kombinasi pemanfaatan televisi, seiring dengan pesatnya perkem- 
bangan TV saat itu. Dan saat ini telah memasuki generasi ke lima dengan dimanfaatkannya komputer dan internet (e-learning atau online learning) untuk e-learning.

Tentu saja, dalam pelaksanaanya kita harus bijak memilih dan menentukan variasi atau kombinasi yang tepat guna dan sesuai dengan kondisi, karakteristik peserta pelatihan tersebut. Modus utama pembelajaran jarak jauh generasi kedua dengan memanfaatkan media cetak yang dikombinasikan dengan video, televisi dan radio sampai saat ini masih sangat potensial untuk konteks Indonesia dan negara berkembang lainnya karena kelemahan dalam hal ICT literacy, akses internet, lemahnya bandwidth, lambatnya kecepatan akses dan infrastruktur ICT lainnya.

Belajar mandiri tidak berarti belajar sendiri. Hal yang terpenting dalam proses belajar mandiri ialah peningkatan kemauan dan keterampilan siswa/peserta didik dalam proses belajar tanpa bantuan orang lain, sehingga pada akhirnya siswa/peserta didik tidak tergantung pada gu$\mathrm{ru}$ /instruktur, pembimbing, teman, atau orang lain dalam belajar. Dalam belajar mandiri siswa/peserta didik akan berusaha sendiri dahulu untuk memahami isi pelajaran yang dibaca atau dilihatnya melalui media audio visual. Kalau mendapat kesulitan barulah bertanya atau mendiskusikannya dengan teman, guru/instruktur atau orang lain. Siswa/peserta didik yang mandiri akan mampu mencari sumber belajar yang dibutuhkannya.

Proses belajar mandiri memberi kesempatan peserta didik untuk mencerna materi ajar dengan sedikit bantuan guru. Mereka mengikuti kegiatan belajar dengan materi ajar yang sudah dirancang khusus sehingga masalah atau kesulitan belajar sudah diantisipasi sebelumnya. Model belajar mandiri ini sangat bermanfaat, karena dianggap luwes, tidak mengikat serta melatih kemandirian siswa agar tidak bergantung atas kehadiran atau uraian materi ajar dari guru. Berdasarkan gagasan keluwesan dan kemandirian inilah belajar mandiri telah ber'metamorfosis' sedemikian rupa, diantaranya menjadi sistem belajar terbuka dan belajar jarak jauh. Perubahan tersebut juga dipengaruhi oleh ilmu-ilmu lain dan kenyataan di lapangan.

Proses belajar mandiri mengubah peran guru atau instruktur, menjadi fasilitator atau perancang proses belajar. Sebagai fasilitator, seorang guru atau instruktur membantu peserta didik mengatasi kesulitan belajar, atau ia dapat menjadi mitra belajar untuk materi tertentu pada program tutorial. Tugas perancang proses belajar mengharuskan guru untuk mengolah materi ke dalam format sesuai dengan pola belajar mandiri. 
Sistem belajar mandiri menuntut adanya materi ajar yang dirancang khusus untuk itu. Menurut Prawiradilaga, 5 beberapa syarat yang harus dipenuhi oleh materi ajar ini adalah:

- Kejelasan rumusan tujuan belajar (umum dan khusus).

- Materi ajar dikembangkan setahap demi setahap, dikemas mengikuti alur desain pesan, seperti keseimbangan pesan verbal dan visual.

- Materi ajar merupakan sistem pembelajaran lengkap, yaitu ada rumusan tujuan belajar, materi ajar, contoh/bukan contoh, evaluasi penguasaan materi, petunjuk belajar dan rujukan bacaan.

- Materi ajar dapat disampaikan kepada siswa melalui media cetak, atau komputerisasi seperti CBT, CD-ROM, atau program audio/video.

- Materi ajar itu dikirim dengan jasa pos, atau menggunakan teknologi canggih dengan internet (situs tertentu) dan e-mail; atau dengan cara lain yang dianggap mudah dan terjangkau oleh peserta didik.

- Penyampaian materi ajar dapat pula disertai program tutorial, yang diselenggarakan berdasarkan jadwal dan lokasi tertentu atau sesuai dengan kesepakatan bersama.

\section{SIMPULAN}

Beberapa hal yang dapat disimpulkan dari pembahasan paper ini adalah sebagai berikut:

1. Pengembangan e-learning untuk saat ini menjadi kecenderungan dan pilihan karena adanya perubahan dalam kehidupan. Pada era globalisasi saat ini terjadi perubahan paradigma dalam dunia pendidikan. Pendidikan yang berlangsung sekarang setidaknya menghadapi dua tantangan. Tantangan yang pertama berasal dari adanya perubahan pandangan terhadap belajar itu sendiri; dan kemajuan teknologi informasi dan komunikasi yang begitu pesat, yang menawarkan berbagai kemudahan dalam pembelajaran.

2. E-learning merupakan aplikasi internet yang dapat menghubungkan antara pendidik dan peserta didik dalam sebuah ruang belajar online. Elearning tercipta untuk mengatasi keterbatasan antara pendidik dan peserta didik, terutama dalam hal ruang dan waktu. Dengan e-learning maka pendidik dan peserta didik tidak harus berada dalam satu dimensi ruang dan waktu. Proses pendidikan dapat berjalan kapan saja dengan mengabaikan kedua hal tersebut.

3. Sistem belajar mandiri (independent learning) berarti pembelajar memiliki otonomi untuk menentukan dan memilih tiga opsi berikut: apa yang akan mereka pelajari; kapan, dimana, bagaimana mereka mempelajarinya; dan kapan, bagaimana mereka membuktikan keberhasialn belajarnya. 


\section{CATATAN AKHIR}

1. Soekartawi, E-learning di Indonesia dan Prospeknya di Masa Mendatang, Makalah disampaikan pada seminar nasional di Universitas Petra, Surabaya, 2003.

2. Yusuf Hadi Miarso, Menyemai Benih Teknologi Pendidikan, Jakarta: Kencana, 2004.

3. A. A. Hartanto dan Ono W. Purbo, Teknologi E-learning Berbasis PHP dan MySQL., Jakarta: Elex Media Komputindo, 2002, dan Soekartawi, Rancangan Instruksional, Jakarta: Rajawali Press, 1999.

4. Soekartawi, ibid.

5. Dewi S. Prawiradilaga dan Eveline Siregar, Mozaik Teknologi Pendidikan, Jakarta: Prenata Media, 2004, h. 194.

\section{DAFTAR PUSTAKA}

Hartanto, A.A, dan Ono W. Purbo, Teknologi E-learning Berbasis PHP dan MySQL, Elex Media Komputindo: Jakarta, 2002.

Heidegger, The Question Concerning Technology, New York: Harper \& Row, 1977.

Idris, Naswil, Pengembangan dan Peranan Sumber Daya Manusia di Era Teknologi Informasi, Semarang, 2001.

McLuhan, Marshall, Understanding Media: The Extensions of Man, New York: McGraw Hill, 1964.

Miarso, Yusuf Hadi, Menyemai Benih Teknologi Pendidikan, Kencana: Jakarta, 2004.

Oetomo, B.S.D., E-education: Konsep, Teknologi dan Aplikasi Internet Pendidikan, Penerbit Andi, Yogyakarta, 2002.

Patmanthara, Saad, Pengintegrasian ICT dengan Menggunakan Model Blended Learning untuk Meningkatkan Mutu Pembelajaran di Sekolah", makalah dalam Seminar dan Pelatihan Implementasi ICT dalam Proses Pembelajaran, LPMP Bandung, 2006.

Prakoso, Kukuh Setyo, Membangun E-learning dengan Moodle, Penerbit Andi: Yogyakarta, 2005.

Prawiradilaga, Dewi S. dan Eveline Siregar, Mozaik Teknologi Pendidikan, Prenata Media: Jakarta, 2004.

PUSTEKKOM, Teknologi Informasi dan Komunikasi (Information Communication Technology), 2006.

Rencana Strategis Depertemen Pendidikan Nasional Tahun 2005-2009 Menuju Pembangunan Pendidikan Nasional Jangka Panjang 2025.

Rochaety, Eti, dkk., Sistem Informasi Manajemen Pendidikan, Bumi Aksara, Jakarta, 2005.

Soekartawi, E-learning di Indonesia dan Prospeknya di Masa Mendatang, makalah disampaikan pada seminar nasional di Universitas Petra, Surabaya, 2003.

Soekartawi, Rancangan Instruksional, Rajawali Press: Jakarta, 1999.

Tam, M., Constructivism, Instructional Design, and Technology: Implication for Transforming Distance Learning, Educational Technology, Volume 3 Number 2. 2000.

Yuhetty, Harina dan Hardjito, Edukasi Net Pembelajaran Berbasis Internet: Tantangan dan Peluangnya, Kencana Media Group dan Universitas Negeri Jakarta: Jakarta, 2004. 